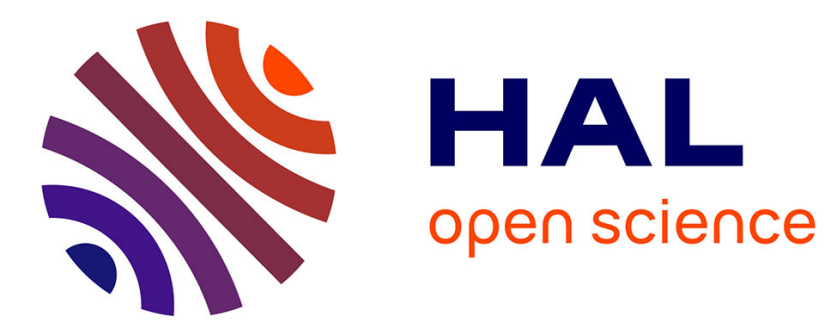

\title{
Versatile synthesis of reversible comb-shaped supramolecular polymers
}

\author{
Cécile Fonteneau, Sandrine Pensec, Laurent Bouteiller
}

\section{To cite this version:}

Cécile Fonteneau, Sandrine Pensec, Laurent Bouteiller. Versatile synthesis of reversible comb-shaped supramolecular polymers. Polymer Chemistry, 2014, 5, pp.2496-2505. 10.1039/c3py01330h . hal01122538

\section{HAL Id: hal-01122538 \\ https://hal.sorbonne-universite.fr/hal-01122538}

Submitted on 4 Mar 2015

HAL is a multi-disciplinary open access archive for the deposit and dissemination of scientific research documents, whether they are published or not. The documents may come from teaching and research institutions in France or abroad, or from public or private research centers.
L'archive ouverte pluridisciplinaire HAL, est destinée au dépôt et à la diffusion de documents scientifiques de niveau recherche, publiés ou non, émanant des établissements d'enseignement et de recherche français ou étrangers, des laboratoires publics ou privés. 
Polym. Chem. 2014, 5, 2496

\title{
Versatile Synthesis of Reversible Comb-Shaped Supramolecular Polymers
}

\author{
Cécile Fonteneau, ${ }^{\mathrm{a}}$ Sandrine Pensec, ${ }^{{ }^{a}}$ and Laurent bouteiller ${ }^{\mathrm{a}}$
}

\begin{abstract}
We report a modular synthetic method toward precisely defined hydrogen-bonded polyacrylates. Various stickers are built into difunctional ATRP (Atom Transfer Radical Polymerization) initiators, which then allow formation of polyacrylates with self-complementary stickers in the middle of the chain, the molar mass of which can be tuned within a large range (from 3 to $100 \mathrm{~kg} \cdot \mathrm{mol}^{-1}$ ). These self-assembling polymers are characterized by FTIR and SANS in solution, showing that comb-shaped supramolecular polymers with a reversible backbone can be obtained.
\end{abstract}

\section{Introduction}

The dynamic character of reversible non covalent interactions in supramolecular polymers is responsible for the appearance of new properties as compared to those of usual covalent polymers. For example, they can display thermoreversible polymer-like properties (such as viscoelasticity), ${ }^{1}$ or form self healing materials. ${ }^{2,3}$

To obtain such materials, the synthesis of polymers bearing hydrogen bonding stickers is a highly successful approach. ${ }^{4,5}$ The introduction of the hydrogen bonding unit can be made by several ways: $^{6}$ postpolymerization functionalization, ${ }^{7-9}$ the use of functionalized monomers, ${ }^{10-13}$ or functionalized initiators or transfer agents. ${ }^{14,15}$ In this context, it is of particular interest to use controlled polymerization strategies to introduce the hydrogen bonding units at precise positions. Numerous techniques have been used such as NMP, ${ }^{16}$ ROP,${ }^{17}$ ROMP,${ }^{18,19}$ RAFT $^{14,20,21}$ and ATRP. ${ }^{15,22-24}$ Various architectures have been obtained: macrocyclics, ${ }^{9,25}$ star-shaped, ${ }^{14,17,26}$ reversibly crosslinked, ${ }^{27-29}$ block copolymers ${ }^{18,19,30}$. However most of these edifices bear at least two stickers per chain, that are designed to form dimers or small clusters which is particularly of interest to obtain thermoplastic elastomers ${ }^{31}$. In contrast, the introduction of a single hydrogen bonding sticker in the middle of the chain, that can form large size aggregates, has been rarely reported. ${ }^{32,33}$ It is however very interesting to form comb-shaped supramolecular polymers to combine the nanostructuration due to the stickers without inducing macroscopic gelation. ${ }^{34,35}$

We have previously reported the synthesis of a comb-shaped supramolecular polymer where the backbone is dynamic. ${ }^{36,37}$ The bisurea synthon formed a ditopic sticker connecting a large number of polyisobutene side chains without cross-linking them. This polymer displays interesting properties in solution and in bulk especially regarding its adhesion on low energy surfaces like poly(dimethylsiloxane) ${ }^{38}$

To further investigate the properties of this type of polymers, we have now developed a modular method for tuning the polymer structure. We report here the synthesis by atom transfer radical polymerization of precisely defined polyacrylates bearing a $\mathrm{H}-$ bonding ditopic sticker in the middle of the chain, where it is possible to tune the self-association strength, the molar mass and the monomer structure. Self-assembly of these functionalized polymers is characterized by FTIR and SANS in solution.

\section{Experimental Section}

\section{Materials}

The following reactants were used without purification: 2chloropropionylchloride (98\%), hydrazine hydrate (64\%), triphosgene (98\%), $\mathrm{CuCl}(99.99 \%), \mathrm{Cu}(0)(<75 \mu \mathrm{m}, 99 \%), \mathrm{CuCl}_{2}$, and $\mathrm{HCl} 4 \mathrm{M}$ in dioxane from Aldrich; 2-aminobutanol (Alfa Aesar, 99\%), di-tertbutyl dicarbonate (Fluka, 99\%), triethylamine (99\%) and palladium on carbon from ABCR, 2,4-dimethyl-5nitroaniline (Apolloscientific), diisopropylethylamine (Acros, 98\%), DMF (Normapur). n-butylacrylate (Acros, 99\%), 2ethylhexylacrylate (Aldrich, 99\%), 3,5,5-trimethylhexylacrylate (Aldrich, 99\%), and pentamethyldiethylenetriamine (PMDETA) (Acros, 99\%) were distilled prior to use. All the anhydrous solvents were used from a solvent purification system (MBraun SPS).

\section{Characterization methods}

NMR spectroscopy. ${ }^{1} \mathrm{H}$ and ${ }^{13} \mathrm{C}$ NMR spectra were recorded on a Bruker AC200 (200MHz) and $\mathrm{AC} 300(300 \mathrm{MHz})$ using $\mathrm{CDCl}_{3}$ and $\left(\mathrm{CD}_{3}\right)_{2} \mathrm{SO}$.

Size exclusion chromatography (SEC). The molar masses $\left(M_{n}\right.$, $\mathrm{M}_{\mathrm{w}}$ ) and the molar mass distribution $\left(Đ=\mathrm{M}_{\mathrm{w}} / \mathrm{M}_{\mathrm{n}}\right)$ were determined by size exclusion chromatography in THF at a flow rate of $1 \mathrm{~mL} / \mathrm{min}$ with two different set-ups. Relative molar masses $\left(\mathrm{M}_{\mathrm{n}, \mathrm{SEC}}(\mathrm{RI})\right.$ were determined using a Waters HPLC 515 pump, a Viscotek VE 5200 automatic injector, two columns thermostated at $40^{\circ} \mathrm{C}$ (PSS SDV, linear M, $8 \mathrm{~mm} \times 300 \mathrm{~mm}$, bead diameter: $5 \mu \mathrm{m}$, separation range: $400-10^{6} \mathrm{Da}$ ), a Viscotek 3580 differential refractive index and a Waters UV 484 detectors. Calculations were made using the Omnisec software. The calibration curve was based on polystyrene standards from Polymer Laboratories. The polystyrene calibration in THF is appropriate for linear poly(n-butylacrylate) samples ${ }^{39}$. Absolute molar masses $\left(\mathrm{M}_{\mathrm{n}, \mathrm{SEC}}\right.$ (triple) $)$ were determined using a Viscotek Detector Array Model TDA 302 equipped with a two angles light scattering detector (LALS: $\theta=7^{\circ}$, RALS: $\theta=90^{\circ}$; laser: $\lambda=670$ 
$\mathrm{nm})$, a refractive index detector $(\lambda=670 \mathrm{~nm})$, a viscosimetric detector and three Polymer Laboratories Mixed C columns thermostated at $40^{\circ} \mathrm{C}$.

MALDI-TOF spectroscopy. MALDI-TOF-MS was performed using a Autoflex III Smartbeam (Bruker) using the flexControl V3 software. The data were treated with the flexAnalysis V3 software. The Maldi mass spectra represent averages over 256 consecutive laser shots. The polymer solutions $\left(5 \mathrm{~g} . \mathrm{L}^{-1}\right)$ were prepared in THF. The matrix, 1,8-dihydroxy-9[10H]anthracenone (dithranol), was also dissolved in THF $\left(25\right.$ g. $\left.\mathrm{L}^{-1}\right)$. A $10 \mu \mathrm{L}$ portion of the polymer solution was mixed with $20 \mu \mathrm{L}$ of the matrix solution. A sodium iodide solution $(10 \mu \mathrm{L}$ of a solution at 20 g. $\mathrm{L}^{-1}$ in $\mathrm{THF}$ ) was finally added to favour ionization by sodium attachment. A $1 \mu \mathrm{L}$ portion of the final solution was deposited onto the sample target. Standards (polystyrenes of known structure, from Polymer Standards Service) were used to calibrate the mass scale.

Fourier transformed infrared spectroscopy. Infrared spectra were recorded on a Nicolet iS10 spectrometer in $\mathrm{KBr}$ cells.

Small Angle Neutron Scattering (SANS). SANS measurements were made at the LLB (Saclay, France) on the PACE instrument, at two distance-wavelength combinations to cover the $4.110^{-3}$ to $0.23 \AA^{-1}$ q-range, where the scattering vector $q$ is defined as usual, assuming elastic scattering, as $q=(4 \pi / \lambda) \sin (\theta / 2)$, where $\theta$ is the angle between incident and scattered beam. Data were corrected for the empty cell signal and the solute and solvent incoherent background. A light water standard was used to normalize the scattered intensities to $\mathrm{cm}^{-1}$ units.

\section{Synthesis of 1}

2-aminobutanol (168 mmol, $14.93 \mathrm{~g}$ ) was dissolved in $300 \mathrm{~mL}$ of anhydrous dichloromethane in a round-bottom flask under argon. Triethylamine (168 mmol, $16.99 \mathrm{~g}$ ) was added with a syringe. The solution was cooled to $0^{\circ} \mathrm{C}$ in an ice bath. Then di-tertbutyl dicarbonate (168 mmol, $36.84 \mathrm{~g}$ ) was added slowly. The solution was allowed to reach room temperature and stirred overnight. Then dichloromethane was evaporated under reduced pressure and the product was dissolved in diethyl ether. This solution was washed with $75 \mathrm{~mL}$ of $\mathrm{HCl} 1 \mathrm{M}$ and then three times with $75 \mathrm{~mL}$ of distilled water. The organic layer was collected and dried with $\mathrm{MgSO}_{4}$. The solvent was removed under reduced pressure. The resulting product is a yellow oil $(27.24 \mathrm{~g}, 86 \%)$.

${ }^{1} \mathbf{H}$ NMR (200 MHz, DMSO) $\delta(\mathrm{ppm}): 0.81\left(\mathrm{t}, 3 \mathrm{H}, \mathrm{CH}_{3}-\mathrm{CH}_{2}\right)$, 1.2-1.6 (m, 9H+2H, $\left.\mathrm{C}\left(\mathrm{CH}_{3}\right)_{3}+\mathrm{CH}_{3}-\mathrm{CH}_{2}\right), 3.23-3.24(\mathrm{~m}, 3 \mathrm{H}$ $\left.\mathrm{CH}_{2}-\mathrm{CH}\right), 4.52(\mathrm{t}, 1 \mathrm{H}, \mathrm{OH}), 6.39(\mathrm{~d}, 1 \mathrm{H}, \mathrm{NH})$.

${ }^{13}$ C NMR (50 MHz, DMSO) $\delta(\mathrm{ppm}): 11.08\left(\mathrm{CH}_{3}-\mathrm{CH}_{2}\right), 24.30$ $\left(\mathrm{CH}_{3}-\mathrm{CH}_{2}\right), 29.06\left(\mathrm{C}\left(\mathrm{CH}_{3}\right)_{3}\right), 54.66(\mathrm{CH}-\mathrm{NH}), 63.80\left(\mathrm{CH}_{2}-\mathrm{OH}\right)$, $77.58\left(\mathrm{C}\left(\mathrm{CH}_{3}\right)_{3}\right), 156.07(\mathrm{CO}-\mathrm{O})$.<smiles>CCC(N)COC(=O)C(C)Cl</smiles>

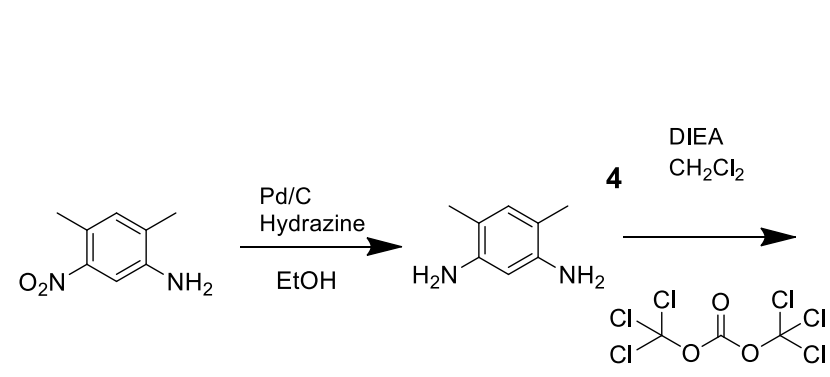<smiles>CCC(COC(=O)C(C)Cl)NC(=O)Nc1cc(NC(=O)NC(CC)COC(=O)C(C)Cl)c(C)cc1C</smiles>

Fig. 1: Synthesis of the xylyl bisurea initiator 5

\section{Synthesis of 2}

1 (144 mmol, $27.24 \mathrm{~g}$ ) was dissolved in $200 \mathrm{ml}$ of anhydrous THF in a round-bottom flask under argon. Triethylamine (144 mmol, $14.57 \mathrm{~g}$ ) was added with a syringe. The solution was cooled to $0^{\circ} \mathrm{C}$ in an ice bath. Then a solution of 2chloropropionylchloride (144 mmol, $18.28 \mathrm{~g}$ ) in $50 \mathrm{~mL}$ of anhydrous THF was added dropwise in one hour in the cooled flask. The solution was allowed to reach room temperature and stirred overnight. The mixture was filtered and the solvent 
removed under reduced pressure. This product was dissolved in diethyl ether and washed 3 times with distilled water. The organic layer was collected and dried with $\mathrm{MgSO}_{4}$. The solvent was removed under reduced pressure. The resulting product is a yellow oil (31 g, 77\%).

${ }^{1}$ H NMR (200 MHz, DMSO) $\delta(\mathrm{ppm}): 0.83\left(\mathrm{t}, 3 \mathrm{H}, \mathrm{CH}_{3}-\mathrm{CH}_{2}\right)$, 1.14-1.50 (m, 9H+2H, C(CH $\left.)_{3}+\mathrm{CH}_{2}-\mathrm{CH}_{3}\right), 1.61(\mathrm{~d}, 3 \mathrm{H}, \mathrm{CH}-$ $\left.\mathrm{CH}_{3}\right), 3.53-3.6\left(\mathrm{~m}, 1 \mathrm{H}, \mathrm{CH}-\mathrm{CH}_{2}\right), 3.88-4.1\left(\mathrm{~m}, 2 \mathrm{H}, \mathrm{O}-\mathrm{CH}_{2}\right)$, 4.57-4.68 (m, 1H, $\left.\mathrm{CH}-\mathrm{CH}_{3}\right), 6.78(\mathrm{~d}, 1 \mathrm{H}, \mathrm{NH})$.

${ }^{13}$ C NMR (50 MHz, DMSO) $\delta(\mathrm{ppm}): 10.54\left(\mathrm{CH}_{3}-\mathrm{CH}_{2}\right), 22.25$ $\left(\mathrm{CH}_{3}-\mathrm{CH}\right), 24.13\left(\mathrm{CH}_{3}-\mathrm{CH}_{2}\right), 28.81\left(\mathrm{C}\left(\mathrm{CH}_{3}\right)_{3}\right), 39.3(\mathrm{CH}-\mathrm{Cl})$, $51.07(\mathrm{CH}-\mathrm{NH}), 67.47\left(\mathrm{CH}_{2}-\mathrm{OCO}\right), 78.25\left(\mathrm{C}\left(\mathrm{CH}_{3}\right)_{3}\right), 156.50$ (NH-CO), 170.32 (CO-O).

\section{Synthesis of 3}

$2(111 \mathrm{mmol}, 31 \mathrm{~g})$ is placed in a round-bottom flask with an ice bath under argon. $\mathrm{HCl} 4 \mathrm{M}$ in dioxane ( $333 \mathrm{mmol}, 88 \mathrm{~mL}$ ), is added with a syringe. The solution was allowed to reach room temperature and stirred overnight. Then dioxane was evaporated under reduced pressure. The crude product was purified by recrystallization in a mixture (toluene/cyclohexane: 70/30). The product is a white powder $(16.5 \mathrm{~g}, 69 \%)$.

${ }^{1} \mathbf{H}$ NMR (200 MHz, DMSO) $\delta(\mathrm{ppm}): 0.93\left(\mathrm{t}, 3 \mathrm{H}, \mathrm{CH}_{3}-\mathrm{CH}_{2}\right)$, 1.50-1.6 (m, $\left.3 \mathrm{H}+2 \mathrm{H}, \mathrm{CH}-\mathrm{CH}_{3}+\mathrm{CH}_{3}-\mathrm{CH}_{2}\right), 3.37(\mathrm{~m}, 1 \mathrm{H}, \mathrm{CH}-$ $\left.\mathrm{NH}_{3}{ }^{+}\right), 4.14-4.28\left(\mathrm{~m}, 2 \mathrm{H}, \mathrm{O}-\mathrm{CH}_{2}\right), 4.72-4.79(\mathrm{~m}, 1 \mathrm{H}, \mathrm{CH}-\mathrm{Cl}), 8.4$ $\left(\mathrm{d}, 3 \mathrm{H}, \mathrm{NH}_{3}^{+}\right.$).

${ }^{13}$ C NMR (50 MHz, DMSO) $\delta(\mathrm{ppm}): 7.4\left(\mathrm{CH}_{3}-\mathrm{CH}_{2}\right), 21.39$ $\left(\mathrm{CH}_{3}-\mathrm{CH}\right), 22.61\left(\mathrm{CH}_{3}-\mathrm{CH}_{2}\right), 51.13(\mathrm{CH}-\mathrm{Cl}), 53.05\left(\mathrm{CH}-\mathrm{NH}_{3}{ }^{+}\right)$, $64.7\left(\mathrm{CH}_{2}-\mathrm{OCO}\right), 169.93$ (CO-O).

\section{Synthesis of 4}

In a round-bottom flask, 2,4-dimethyl-5-nitroaniline $(69 \mathrm{mmol}$, $11.46 \mathrm{~g}$ ), palladium on carbon ( $9 \mathrm{mmol}, 0.96 \mathrm{~g}$ ) and ethanol (400 $\mathrm{mL})$ were stirred. Then hydrazine hydrate $(1.02 \mathrm{~mol}, 50 \mathrm{~mL})$ was added. The mixture was heated under reflux during 5 days, filtered on celite and then ethanol was removed under reduced pressure. The product was dissolved in $400 \mathrm{~mL}$ of ethyl acetate and washed three times with distilled water. The organic layer was collected and dried with $\mathrm{MgSO}_{4}$. The solvent was removed under reduced pressure. The resulting product is a white-grey powder $(5.4 \mathrm{~g}, 60 \%)$.

${ }^{1}$ H NMR (200 MHz, DMSO) $\delta(\mathrm{ppm}): 1.9$ (s, 6H, $\left.\mathrm{CH}_{3}-\mathrm{Ph}\right), 4.3$ (s, 4H, NH $\left.H_{2}-\mathrm{Ph}\right), 6.0$ (s, $\left.1 \mathrm{H}, H-\mathrm{Ph}\right), 6.5$ (s, $\left.1 \mathrm{H}, H-\mathrm{Ph}\right)$.

${ }^{13}$ C NMR (50 MHz, DMSO) $\delta(\mathrm{ppm}): 16.8\left(\mathrm{CH}_{3}-\mathrm{Ph}\right), 101.06(\mathrm{Ph}-$ H), $109.94\left(P h-\mathrm{CH}_{3}\right), 132.04(P h-\mathrm{H}), 144.84\left(P h-\mathrm{NH}_{2}\right)$.

\section{Synthesis of 5}

Diisopropylethylamine (17 mmol, $3 \mathrm{~mL})$ and 4 ( $8.4 \mathrm{mmol}, 1.14$ g) were dissolved in $15 \mathrm{~mL}$ of anhydrous dichloromethane under argon and added with a syringe-pump $(3.5 \mathrm{~mL} / \mathrm{h})$ to a roundbottom flask containing triphosgene $(5.6 \mathrm{mmol}, 1.67 \mathrm{~g})$ dissolved in $30 \mathrm{~mL}$ of anhydrous dichloromethane under argon. After one hour stirring at room temperature, a solution of 3 (18 mmol, 3.7 g) in $20 \mathrm{~mL}$ of anhydrous dichloromethane and diisopropylethylamine ( $35 \mathrm{mmol}, 6 \mathrm{~mL})$ were added to the mixture. The reaction was followed by infrared spectroscopy until the disappearance of the NCO band at $2270 \mathrm{~cm}^{-1}$. When the reaction was over, the solvent was removed under reduced pressure. The crude product was purified by two recrystallizations in acetonitrile. A white solid is obtained (2.6 g, $58 \%)$.

${ }^{1}$ H NMR (200 MHz, DMSO) $\delta(\mathrm{ppm}): 0.90\left(\mathrm{t}, 6 \mathrm{H}, \mathrm{CH}_{3}-\mathrm{CH}_{2}\right)$, 1.30-1.6 (m, 6H+4H, CH-CH $\left.{ }_{3} \mathrm{CH}_{3}-\mathrm{CH}_{2}\right), 2.08\left(\mathrm{~s}, 6 \mathrm{H}, \mathrm{CH}_{3}-\mathrm{Ph}\right)$, $3.8(\mathrm{~m}, 2 \mathrm{H}, \mathrm{CH}-\mathrm{NH}), 4.1\left(\mathrm{~m}, 4 \mathrm{H}, \mathrm{CH}_{2}-\mathrm{O}\right), 4.72(\mathrm{~m}, 2 \mathrm{H}, \mathrm{CH}-\mathrm{Cl})$, $6.32(\mathrm{~m}, 2 \mathrm{H}, \mathrm{CH}-\mathrm{N} H-\mathrm{CO}), 6.86(\mathrm{~s}, 1 \mathrm{H}, H-\mathrm{Ph}), 7.54$ (s, 2H, CO$\mathrm{N} H-\mathrm{Ph}), 8.00$ (s, $1 \mathrm{H}, H-\mathrm{Ph})$.

${ }^{13}$ C NMR (50 MHz, DMSO) $\delta(\mathrm{ppm}): 10.54\left(\mathrm{CH}_{3}-\mathrm{CH}_{2}\right), 17.39$ $\left(\mathrm{CH}_{3}-\mathrm{Ph}\right), 21.63\left(\mathrm{CH}_{3}-\mathrm{CH}\right), 24.77\left(\mathrm{CH}_{3}-\mathrm{CH}_{2}\right), 49.55(\mathrm{CH}-\mathrm{Cl})$, 53.50 (CH-NH), $67.21\left(\mathrm{CH}_{2}-\mathrm{OCO}\right), 116.24(P h-\mathrm{H}) ; 122.56(P h-$ $\left.\mathrm{CH}_{3}\right), 132.05(P h-\mathrm{H}), 136.27(P h-\mathrm{NH}), 155.51(\mathrm{NH}-\mathrm{CO}-\mathrm{NH})$, $169.74(\mathrm{CO}-\mathrm{O})$

HRMS m/z $\left[\mathrm{MNa}^{+}\right]$

$\mathrm{C}_{24} \mathrm{H}_{36} \mathrm{O}_{6} \mathrm{~N}_{4} \mathrm{Cl}_{2}$ calculated 569.19055 measured 569.19041

General procedure for the ATRP of n-butylacrylate initiated by 5

Copper chloride (0.913 mmol, $90 \mathrm{mg})$, PMDETA (0.913 mmol, $158 \mathrm{mg}), 5(0.913 \mathrm{mmol}, 0.5 \mathrm{~g})$, DMF $(1.1 \mathrm{~mL})$ and $\mathrm{n}-$ butylacrylate $(77 \mathrm{mmol}, 10 \mathrm{~mL})$ were introduced in a Schlenk flask sealed with a rubber septum. This mixture was degassed by three freeze/pump/thaw cycles. The schlenk was placed in an oil bath at $80^{\circ} \mathrm{C}$. Samples were withdrawn periodically from the reaction to determine conversion by NMR and molar mass by SEC. After completion of the reaction, the flask was opened to air and ethyl acetate was added. This solution was washed with brine until the organic layer was copper free (yellow solution). The organic layer was collected and dried with $\mathrm{MgSO}_{4}$. The solvent was removed under reduced pressure.

${ }^{1} \mathbf{H}$ NMR (200 MHz, DMSO) $\delta(\mathrm{ppm}): 0.89\left(\mathrm{t},\left(\mathrm{CH}_{3}-\mathrm{CH}_{2}\right)_{\mathrm{n}}\right), 1.3$ (m, $\left.\left(\mathrm{CH}_{3}-\mathrm{CH}_{2}\right)_{\mathrm{n}}\right), 1.51\left(\mathrm{~m},\left(\mathrm{CH}_{3}-\mathrm{CH}_{2}-\mathrm{CH}_{2}\right)_{\mathrm{n}}\right), 1.77$ (br, $\left(\mathrm{CH}_{2}-\mathrm{CH}-\right.$ $\left.\mathrm{COO})_{\mathrm{n}}\right), 2.06\left(\mathrm{~s}, 6 \mathrm{H}, \mathrm{Ph}-\mathrm{CH}_{3}\right), 2.2\left(\mathrm{br},\left(\mathrm{CH}_{2}-\mathrm{CH}-\mathrm{COO}\right) \mathrm{n}\right), 3.99$ (br, $\left.\left(\mathrm{CH}_{2}-\mathrm{O}\right)_{\mathrm{n}}\right), 6.28(\mathrm{~d}, 2 \mathrm{H}, \mathrm{CH}-\mathrm{N} H-\mathrm{CO}), 6.85(\mathrm{~s}, 1 \mathrm{H}, \mathrm{Ph}-H)$, 7.51 (s, 2H, CO-NH-Ph), 7.99 (s, 1H, Ph- $H$ ).

${ }^{13} \mathbf{C}$ NMR (75 MHz, DMSO) $\delta(\mathrm{ppm}): 10.9\left(\mathrm{CH}_{3}-\mathrm{CH}_{2}\right), 13.77$ $\left(\left(\mathrm{CH}_{3}-\mathrm{CH}_{2}\right)_{\mathrm{n}}\right), 18.16\left(\mathrm{Ph}-\mathrm{CH}_{3}\right), 19.69\left(\left(\mathrm{CH}_{3}-\mathrm{CH}_{2}\right)_{\mathrm{n}}\right), 25.8\left(\mathrm{CH}_{3}-\right.$ $\left.\mathrm{CH}_{2}\right), 31.35\left(\left(\mathrm{CH}_{3}-\mathrm{CH}_{2}-\mathrm{CH}_{2}\right)_{\mathrm{n}}\right), 32.5\left(\left(\mathrm{CH}_{2}-\mathrm{CH}-\mathrm{COO}\right) \mathrm{n}\right), 42.44$ $\left(\left(\mathrm{CH}_{2}-\mathrm{CH}-\mathrm{COO}\right)_{\mathrm{n}}\right), 50.85(\mathrm{CH}-\mathrm{COO}), 55.1\left(\mathrm{CH}_{3}-\mathrm{CH}\right), 56.6(\mathrm{CH}-$ $\mathrm{NH}), 65\left(\left(\mathrm{CH}_{2}-\mathrm{O}\right)_{\mathrm{n}}\right), 66.72\left(\mathrm{CH}_{2}-\mathrm{O}\right), 119.48(P h-\mathrm{H}), 125.8(P h-$ $\left.\mathrm{CH}_{3}\right), 132.49(P h-\mathrm{H}), 136.31(P h-\mathrm{NH}), 156.57(\mathrm{NH}-\mathrm{CO}-\mathrm{NH})$, $\left.169.76(C O-O), 175.31((C O-O))_{n}\right)$.

\section{Results and discussion}

In order to be able to reach high molar masses, a functionalized initiator strategy was selected. 


\begin{tabular}{|c|c|c|c|c|c|c|c|}
\hline Sample & {$[\mathrm{M}] /[\mathrm{I}] /[\mathrm{CuX}]^{\mathrm{a}}$} & Conversion $^{\mathrm{b}}$ & $\mathrm{M}_{\mathrm{n}, \mathrm{th}}{ }^{\mathrm{c}}(\mathrm{g} / \mathrm{mol})$ & $\mathrm{M}_{\mathrm{n}, \mathrm{SEC}(\mathrm{RI})}{ }^{\mathrm{d}}(\mathrm{g} / \mathrm{mol})$ & $\mathrm{M}_{\mathrm{n}, \mathrm{SEC} \text { (triple) }}{ }^{\mathrm{e}}(\mathrm{g} / \mathrm{mol})$ & $\mathrm{M}_{\mathrm{n} N \mathrm{NMR}}{ }^{\mathrm{b}}(\mathrm{g} / \mathrm{mol})$ & $\bigoplus^{d}$ \\
\hline CF106 & $42 / 1 / 0.5^{\mathrm{f}, \mathrm{i}}$ & 0.56 & 3600 & 3500 & - & 3800 & 1.24 \\
\hline CF151 & $86 / 1 / 1^{\mathrm{f}, \mathrm{i}}$ & 0.65 & 7700 & 8500 & - & 8800 & 1.23 \\
\hline CF76 & $253 / 1 / 2^{\mathrm{g}, \mathrm{i}}$ & 0.77 & 25400 & 24100 & 25200 & - & 1.23 \\
\hline CF87 & $552 / 1 / 2^{\mathrm{g}, \mathrm{i}}$ & 0.61 & 43700 & 37100 & 43100 & - & 1.2 \\
\hline CF89 & $824 / 1 / 3^{\mathrm{g}, \mathrm{i}}$ & 0.56 & 59500 & 51200 & 60500 & - & 1.22 \\
\hline CF92 & $1099 / 1 / 4^{\mathrm{g}, \mathrm{i}}$ & 0.71 & 100300 & 72900 & - & - & 1.7 \\
\hline CF99 & $1000 / 1 / 0.5^{\mathrm{h}, \mathrm{i}}$ & 0.80 & 102400 & 83000 & 115000 & - & 1.34 \\
\hline CF126 & $76 / 1 / 1^{\mathrm{f}, \mathrm{j}}$ & 0.65 & 8700 & 8100 & - & 9170 & 1.26 \\
\hline CF128 & $56 / 1 / 1^{\mathrm{f}, \mathrm{k}}$ & 0.67 & 8000 & 7800 & - & 9020 & 1.23 \\
\hline
\end{tabular}

${ }^{\mathrm{a}}[\mathrm{CuX}] /[\mathrm{PMDETA}]=1{ }^{\mathrm{b}}$ Calculated by ${ }^{\mathrm{l}} \mathrm{H}$ NMR ${ }^{\mathrm{c}}$ Theoretical $\mathrm{M}_{\mathrm{n}}$ at final conversion $=\left([\mathrm{M}]_{0} /[\mathrm{I}]_{0}\right) *$ conversion $* \mathrm{MW}(\mathrm{M})+\mathrm{MW}(\mathrm{I}){ }^{\mathrm{d}}$ Evaluated by SEC in THF using polystyrene standards ${ }^{\mathrm{e}}$ Evaluated by SEC triple detection in THF ${ }^{\mathrm{f}} \mathrm{X}=\mathrm{Cl}^{\mathrm{g}} \mathrm{X}=\mathrm{Br}^{\mathrm{h}} \mathrm{ARGET}[\mathrm{M}] /[\mathrm{I}] /[\mathrm{Cu}(0)] /\left[\mathrm{CuCl} l_{2}\right]=1000 / 1 / 0.5 / 0.25{ }^{\mathrm{i}} \mathrm{M}=\mathrm{n}-\mathrm{butylacrylate}{ }^{\mathrm{j}}$ $\mathrm{M}=2$-ethylhexylacrylate ${ }^{\mathrm{k}} \mathrm{M}=3,5,5$-trimethylhexylacrylate

\section{Synthesis of the xylyl bisurea ATRP initiator}

A symmetrical xylyl bisurea bearing a halogen at each extremity was synthesized to initiate ATRP polymerization of acrylates (Figure 1). First an ammonium functionalized initiator was obtained in three steps. The purpose was to introduce a halogen atom activated by an ester function by reacting an amino alcohol with 2-chloropropionylchloride. The amino alcohol chosen (2aminobutanol) allows to introduce an ethyl branch next to the urea groups, which is expected to promote solubility without putting too much steric hindrance. ${ }^{52}$ To avoid the reaction of the amino group with the acid chloride, the amino group was first protected with diboc. After coupling, the amino function of $\mathbf{2}$ was deprotected with an anhydrous $\mathrm{HCl}$ solution in dioxane, thus avoiding hydrolysis of the ester function. The ammonium $\mathbf{3}$ was purified by recrystallization to give a white powder with an overall yield of $46 \%$ for the three steps. In a fourth step, the xylyl bisurea 5 was obtained by reacting the ammonium with a diisocyanate. 1,3-dimethyl-4,6-diisocyanatobenzene was prepared in situ by reacting the corresponding aromatic diamine 4 with triphosgene and then the ammonium $\mathbf{3}$ was added to give the
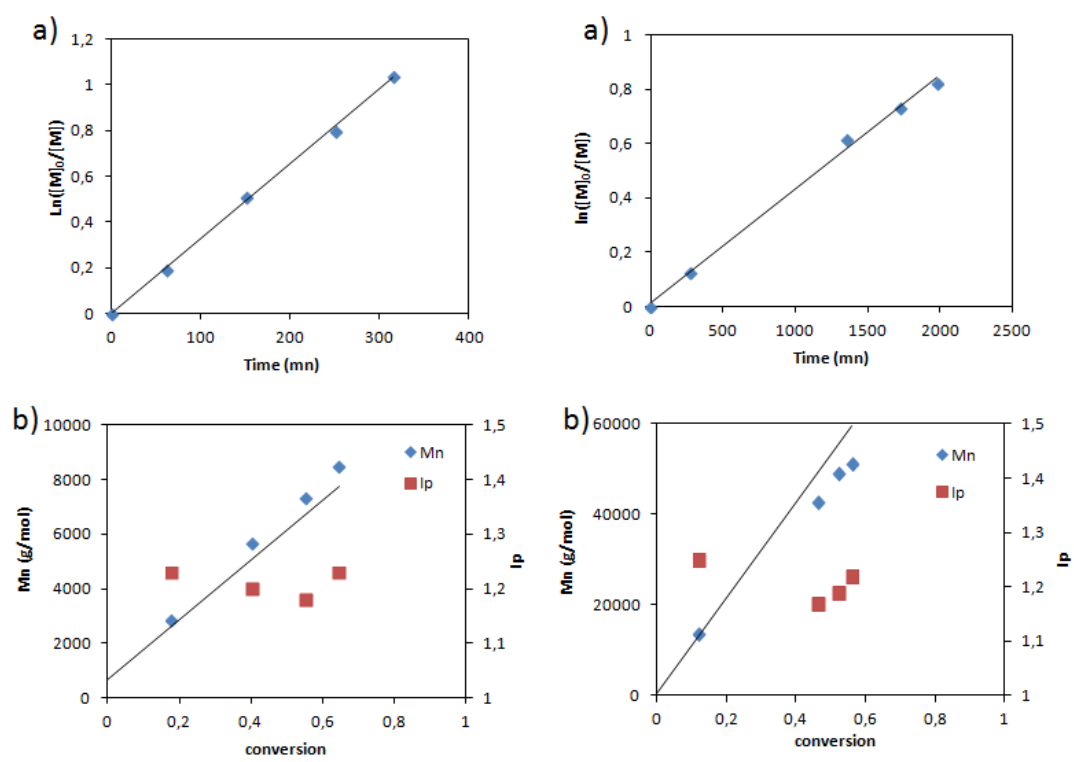

c)

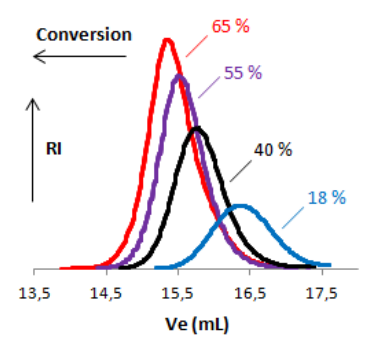

c)

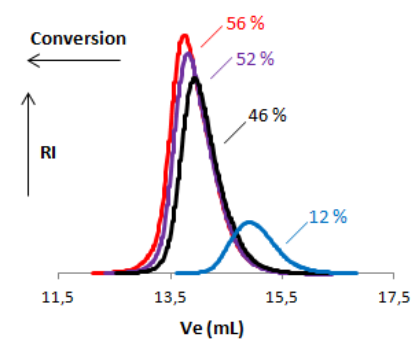

Fig. 2: Kinetic data for the ATRP of $n$-butylacrylate initiated by 5 in $10 \%$ DMF at $80^{\circ} \mathrm{C}$. Left (CF151): [BA]/[5]/[CuCl]/[PMDETA] = 86/1/1/1. Right (CF89): $[\mathrm{BA}] /[5] /[\mathrm{CuBr}] /[\mathrm{PMDETA}]=824 / 1 / 3 / 3$. a) Evolution of monomer conversion $\left(\ln \left([\mathrm{M}]_{0} /[\mathrm{M}]\right)\right)$ versus time; $\left.b\right)$ Evolution of molar mass and polydispersity versus conversion (the line represents the theoretical molar mass); c) Size exclusion chromatograms versus monomer conversion. 


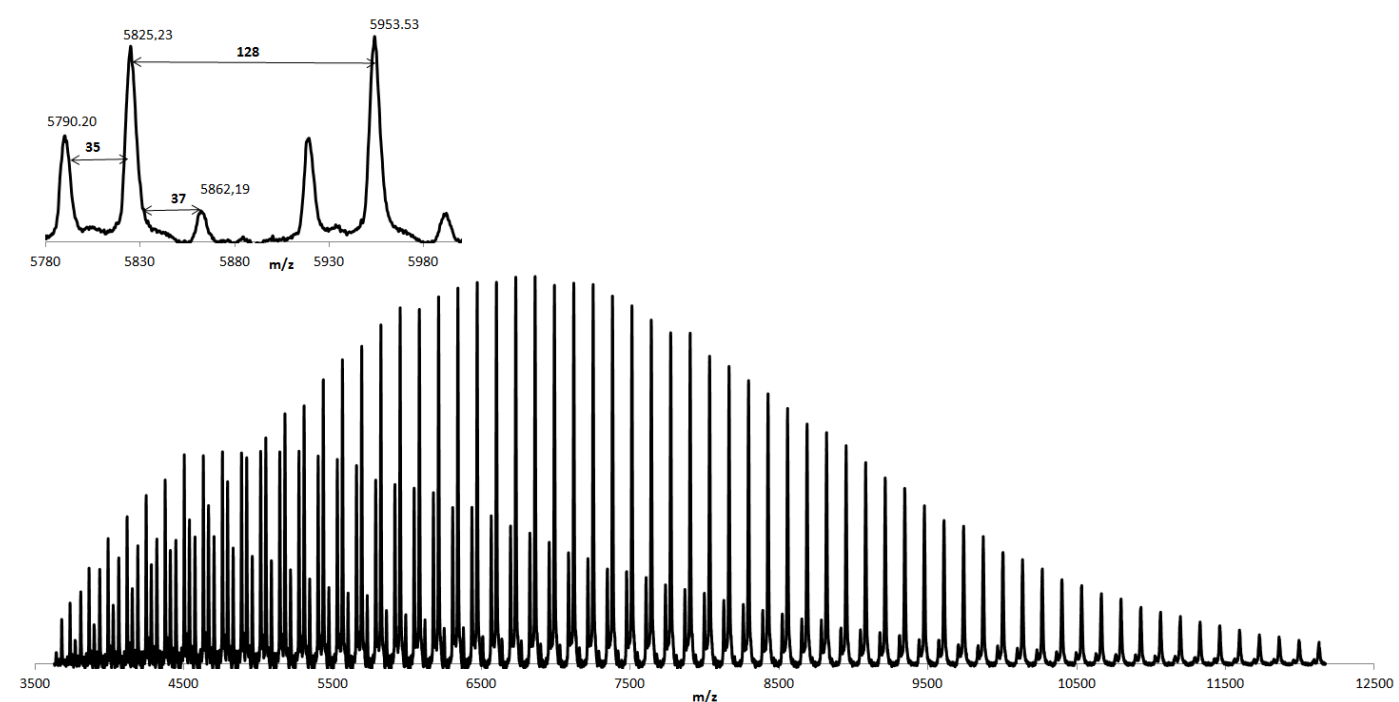

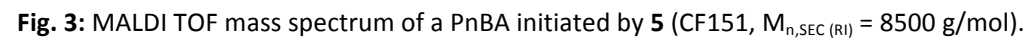

targeted bisurea. The crude product was purified by recrystallizations to give a white solid 5 with a good yield (58\%). NMR and HRMS analysis confirmed the structure and the purity of the product.

\section{Polymerization of n-butylacrylate by ATRP with the xylyl} bisurea initiator

The initiation efficiency of xylyl bisurea 5 was first tested in the ATRP polymerization of n-butylacrylate (BA) in DMF at $80^{\circ} \mathrm{C}$ using the $\mathrm{CuCl}$ (or $\mathrm{CuBr}$ )/PMDETA system as catalyst. This catalytic system is well known to afford a good control of acrylate polymerization. ${ }^{40,41}$ All the polymerizations were carried out with a ratio $[\mathrm{CuX}] /[\mathrm{PMDETA}]$ of $1 / 1$ to have a good control of the polymerization and a reasonable reaction time. The ratio [initiator $] /[\mathrm{CuX}]$ was adjusted for each synthesis to have a reasonable reaction time whatever the amount of BA. Finally the $[\mathrm{BA}] /[$ initiator] ratio was fixed by the expected molar mass of the polymer. To avoid irreversible termination, the targeted final conversion was $70 \% .10 \%$ w of DMF was added to improve the solubility of the urea initiator. The latter was not completely dissolved at room temperature but at $80^{\circ} \mathrm{C}$ a homogeneous solution was observed.

Table 1 as well as Figure 2 presents the polymerization results. With a low monomer to initiator ratio $[\mathrm{M}] /[\mathrm{I}]=86(\mathrm{CF} 151)$, polymerization resulted in a good control. The conversion reached $65 \%$ after $5 \mathrm{~h} 15$, the molar mass increased linearly with monomer conversion and the dispersity index remained below 1.3 (Figure 2 left). Moreover $\ln \left(\left[\mathrm{M}_{0}\right] /[\mathrm{M}]\right)$ increased linearly with time indicating that the concentration of the propagating species remained constant during the polymerization. As expected, the chromatograms show a displacement of the peak toward higher molar masses with increasing conversion.

For high molar masses (Figure 2 right), the evolution of the molar mass versus conversion is qualitatively correct but shows a deviation of the experimental value from the theoretical one at high conversion. This is also visible in Table 1: for high molar masses, a discrepancy between theoretical and experimental molar masses measured by size exclusion chromatography with a refractive index detector is observed. In order to obtain the absolute molar masses, the same polymers were analysed by size exclusion chromatography with a triple detection (refractive index, dynamic light scattering and viscosimetry). Results indicate that the experimental molar masses are in fact very close to the theoretical values. This suggests that our polymers are branched. Indeed, poly(n-butylacrylate) (PnBA) is well known to be a branched polymer, ${ }^{42-44}$ and this explains why the hydrodynamic volume of the polymers is lower than expected.

The chemical structure of the polymer was determined by means of proton and carbon nuclear magnetic resonance $\left({ }^{1} \mathrm{H}\right.$ NMR and ${ }^{13} \mathrm{C}$ NMR). The characteristic NH (7.5 and $\left.6.3 \mathrm{ppm}\right)$ and aromatic peaks ( 8 and $7.6 \mathrm{ppm}$ ) of the sticker were observed by ${ }^{1} \mathrm{H}$ NMR (see $\left.\mathrm{ESI}^{\dagger}\right)$. The carbonyls (156 ppm) and aromatic carbons (136 to $123 \mathrm{ppm}$ ) were also visible on ${ }^{13} \mathrm{C}$ NMR spectra. The structure of this polymer was confirmed by MALDI-TOF mass spectrometry analysis. The MALDI mass spectrum (Figure 3) reveals a main distribution of peaks separated by $128 \mathrm{Da}$ (BA repeat unit). The experimental values of the peaks in this main distribution are in good agreement with the theoretical values for the expected structure, with chlorine at each end. A second distribution in much smaller proportion is also present and separated from the first one by 35 units. It corresponds to the loss of a chlorine atom replaced by a hydrogen atom. This loss of

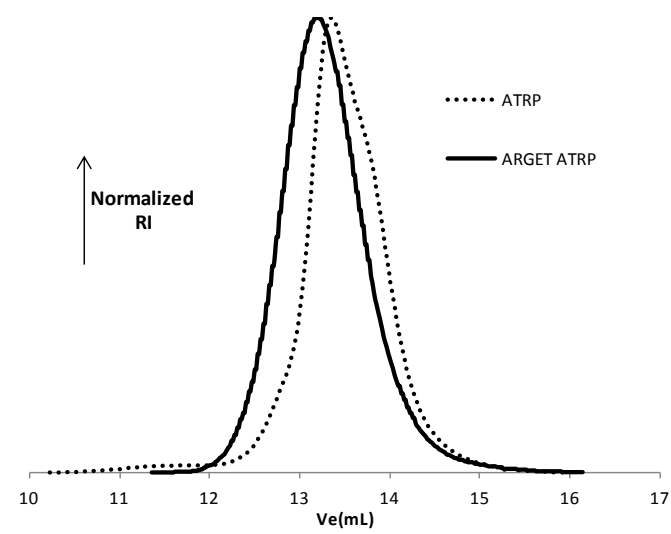

Fig. 4: Size exclusion chromatograms of the PnBAs obtained by ATRP (CF92) or ARGET ATRP (CF99), [BA]/[5] = 1000/1. 
Table 2: Characteristics of the PnBAs with various stickers

\begin{tabular}{cccccccc} 
Sample & Initiator & {$[\mathrm{M}] /[\mathrm{I}] /[\mathrm{CuX}]$} & Conversion $^{\mathrm{a}}$ & $\mathrm{M}_{\mathrm{n}, \mathrm{th}}(\mathrm{g} / \mathrm{mol})^{\mathrm{b}}$ & $\mathrm{M}_{\mathrm{n}, \mathrm{SEC}(\mathrm{RI})}{ }^{\mathrm{c}}(\mathrm{g} / \mathrm{mol})$ & $\mathrm{M}_{\mathrm{n} \text { NMR }}{ }^{\mathrm{a}}\left(\mathrm{g} / \mathrm{mol}^{2}\right.$ & $\mathrm{D}^{\mathrm{c}}$ \\
\hline CF50 & Tolyl bisurea & $86 / 1 / 1$ & 0.63 & 7500 & 7300 & 7500 & 1.17 \\
CF62 & MDI bisurea & $86 / 1 / 1$ & 0.75 & 9000 & 8500 & 8400 \\
CF151 & Xylyl bisurea & $86 / 1 / 1$ & 0.65 & 7700 & 8500 & 8800 \\
CF108 & Trisurea & $87 / 1 / 1$ & 0.67 & 8100 & 8100 & 1.15 \\
& & & & & 8000 & 1.23
\end{tabular}

${ }^{\text {a }}$ Calculated by ${ }^{1} \mathrm{H}$ NMR ${ }^{\mathrm{b}}$ Theoretical $\mathrm{M}_{\mathrm{n}}$ at final conversion $=\left([\mathrm{M}]_{0} /[\mathrm{I}]_{0}\right) *$ conversion $* \mathrm{MW}(\mathrm{M})+\mathrm{MW}(\mathrm{I}){ }^{\mathrm{c}}$ Evaluated by SEC in THF using polystyrene standards

halogen is well known to occur in ATRP when the conversion is high. ${ }^{45,46}$ Finally a very small third population is observed at low molar masses. It is separated from the main population by 37 units but it could not be attributed. When high molar masses were targeted (Table 1), a good control was possible only up to 60000 $\mathrm{g} / \mathrm{mol}$ (CF89, Figure 2 right). For a targeted molar mass of $110000 \mathrm{~g} / \mathrm{mol}$ in these conditions (CF92), the reaction was very slow (3-4 days) and the control was not as good as for the other polymerizations. Especially a bimodal peak with a large dispersity index (1.7) was observed by SEC (Figure 4). To solve this problem, ARGET (activator regenerated electron transfer) $\mathrm{ATRP}^{47,48}$ was used with $\mathrm{Cu}(0)$ as reducing agent and with a ratio of $[$ initiator $] /[\mathrm{Cu}(0)] /\left[\mathrm{CuCl}_{2}\right] /[\mathrm{PMDETA}]: 1 / 0.5 / 0.25 / 0.25$. The reaction was carried out at $80^{\circ} \mathrm{C}$ and was followed by $\mathrm{SEC}$ and NMR. The reaction was faster than with conventional ATRP (17 $\mathrm{h}$ instead of 4 days) and the resulting polymer is well controlled with a dispersity of 1.3 (Figure 4).

Polymerization of other acrylate monomers with the xylyl bisurea initiator

To obtain a range of polyacrylates with a xylyl bisurea sticker but with different structures and polarities, we have chosen 2ethylhexylacrylate and 3,5,5-trimethylhexylacrylate as monomers. The polymerizations were carried out under the same conditions as with $\mathrm{BA}\left(80^{\circ} \mathrm{C}\right.$, xylyl bisurea $5, \mathrm{CuCl} / \mathrm{PMDETA}$ as catalytic system). As shown in Table 1 and $\mathrm{ESI}^{\dagger}$, polymerizations resulted in both cases in a good control.

\section{Polymerization of n-butylacrylate with various urea initiators}

These results have validated the method using xylyl bisurea as initiator for ATRP polymerizations. We have previously shown that for small molecules it is possible to tune the self-association strength of urea stickers by changing the number of urea functions and the spacer between these functions. For example, bisureas with a tolyl spacer self-assemble less strongly than bisureas with a xylyl spacer. ${ }^{49}$ In order to consider this parameter in our system, we have prepared initiators with a different number of urea functions (2 or 3 ) and with different spacers (xylyl, tolyl and MDI) (Figure 5). Tolyl bisurea (6), MDI bisurea (7) and trisurea (8) initiators (Figure 5) were prepared by the same approach as the xylyl bisurea initiator. Note that for tolyl and MDI initiators, terminal halogens are either chlorine or bromine or a mixture of both, with no consequence on the control of the polymerization (see $\mathrm{ESI}^{\dagger}$ ). Tolyl and MDI bisurea initiators were obtained by reacting the ammonium 3' (see ESI') with the corresponding commercially available diisocyanates. The tolyl bisurea was purified by precipitation in cyclohexane with a yield of $56 \%$. The MDI bisurea was purified by column chromatography with a yield of $33 \%$. The diisocyanate required for the synthesis of trisurea (8) was prepared by partial hydrolysis of TDI ${ }^{50}$ A recrystallization in methanol afforded a pure initiator with a yield of $50 \%$.

The control of the polymerizations was slightly better with the MDI and tolyl bisurea initiators which are soluble at room temperature (dispersity index below 1.2) than for xylyl bisurea and trisurea initiators soluble only at $80^{\circ} \mathrm{C}$. However in all cases<smiles>[X]C(C)C(=O)OCC(CC)NC(=O)Nc1ccc(C)c(NC(=O)NC(CC)COC(=O)C([X])C)c1</smiles>

c) b)<smiles>[X]C(C)C(=O)OCC(CC)NC(=O)Nc1ccc(Cc2ccc(NC(=O)NC(CC)COC(=O)C([X])C)cc2)cc1</smiles>

$\mathrm{X}=\mathrm{Cl} / \mathrm{Br}$

$\mathrm{X}=\mathrm{Cl} / \mathrm{Br}$<smiles>CCC(COC(=O)C(C)Cl)NC(=O)Nc1cc(NC(=O)Nc2ccc(C)c(NC(=O)NC(CC)COC(=O)C(C)Cl)c2)ccc1C</smiles>

8

Fig. 5: Structures of a) tolyl bisurea b) MDI bisurea and c) trisurea initiators. 

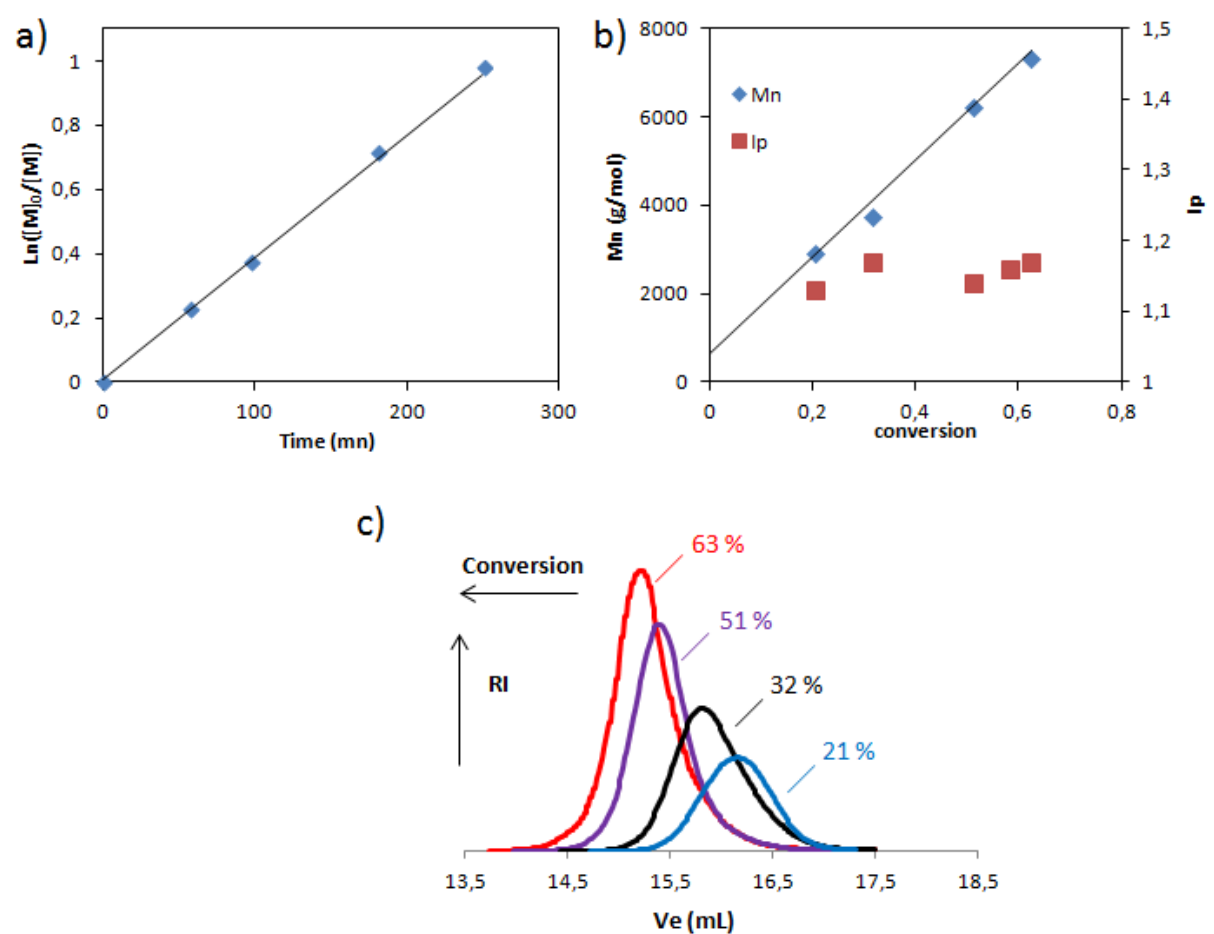

Fig. 6: Kinetic data for the ATRP of BA initiated by tolyl bisurea initiator 6 in $10 \%$ DMF at $80^{\circ} \mathrm{C}$ with $[\mathrm{BA}] /[6] / \mathrm{CuBr} / \mathrm{PMDETA}: 86 / 1 / 1 / 1$.

the control of the polymerization is good (Table 2). For example, the kinetic monitoring of the polymerization of BA initiated by the tolyl bisurea initiator (Figure 6) shows a linear increase of the $\ln \left([\mathrm{M}]_{0} /[\mathrm{M}]\right)$ versus time and of molar mass versus conversion.

\section{Characterization of the supramolecular assemblies in solution}

\section{Infrared spectroscopy}

The self-assembly of bis or trisurea functionalized polyacrylates was investigated by FTIR spectroscopy in solution. Figure 7 shows the FTIR spectra of a xylyl bisurea PnBA $\left(\mathrm{M}_{\mathrm{n}}=8500\right.$ $\mathrm{g} / \mathrm{mol}$ ) at different concentrations in toluene.

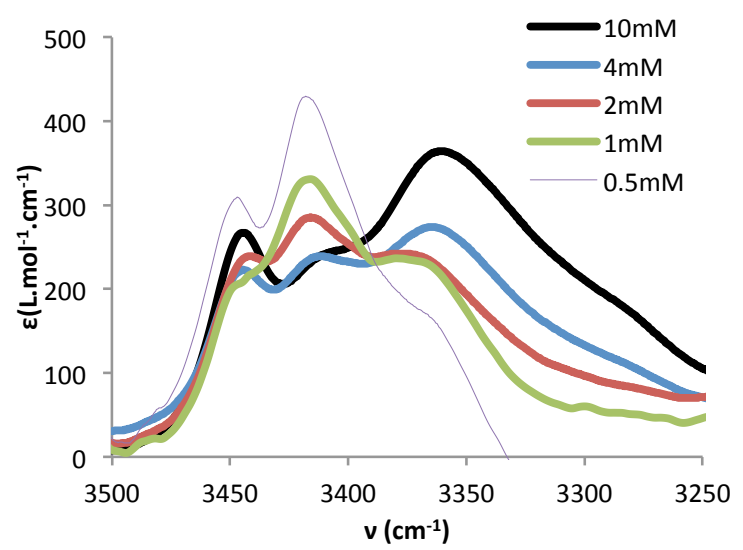

Fig. 7: Infrared spectra of xylyl bisurea PnBA (CF151) at various concentrations in toluene.

The spectrum reveals three main bands: the inter-urea hydrogenbonded N-H vibration band $\left.\left(3350-3250 \mathrm{~cm}^{-1}\right)\right)^{51}$ the free N-H vibration band at $3450 \mathrm{~cm}^{-1}$ and an intermediate band at $3410 \mathrm{~cm}^{-}$ ${ }^{1}$. Because of its weak frequency shift, the latter is attributed to the N-H vibration band for (intermolecular or intramolecular) association of urea with the ester function of BA. ${ }^{52}$

The proportion of inter-urea hydrogen-bonded N-H groups (3300 $\mathrm{cm}^{-1}$ ) decreases with decreasing the concentration. At the same time, the contribution of the N-H band at $3410 \mathrm{~cm}^{-1}$ attributed to association between urea and ester functions increases. That means that when the solution is diluted, urea-urea interactions are broken in favour of urea-ester interactions. This suggests that the urea-ester hydrogen bonds are predominantly intramolecular.

Therefore, the spectra show that intermolecular association is negligible below $1 \mathrm{mM}$. This relatively weak self-association is due to the steric bulk of the polymer chains and to the competing hydrogen bonds of the ester groups, because the low molar mass analogue bearing the same sticker is fully assembled at $1 \mathrm{mM}$ in toluene. ${ }^{49}$ Importantly, above $10 \mathrm{mM}$, intermolecular association becomes preponderant.

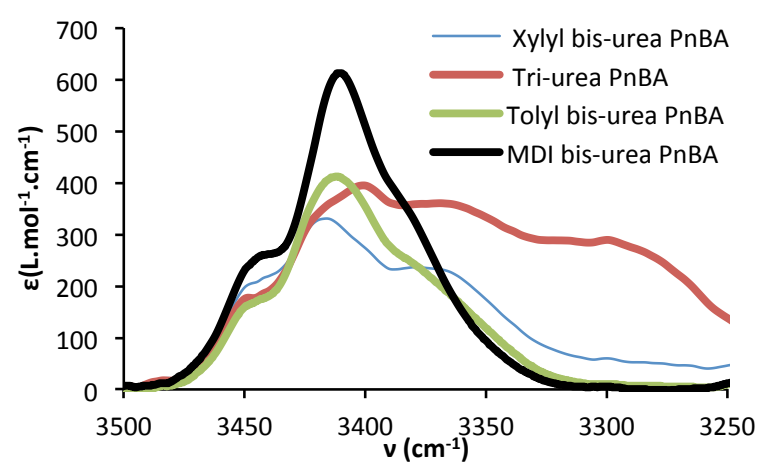

Fig. 8: Infrared spectrum of polyacrylates bearing various urea stickers at $1 \mathrm{mM}$ in toluene $\left(\mathrm{M}_{\mathrm{n}}\right.$ ca $\left.8000 \mathrm{~g} / \mathrm{mol}\right)$. 
The comparison of the spectra of PnBAs bearing various urea stickers (Figure 8) reveals that at $1 \mathrm{mM}$ in toluene the proportion of inter-urea hydrogen bonds is low for all bisurea stickers. For all bisurea polyacrylates, the main band is the $\mathrm{N}-\mathrm{H}$ vibration band for intramolecular association of urea with the ester function of BA. This means that bisurea polyacrylates are very weakly associated. In contrast, for trisurea a large proportion of inter-urea hydrogen bonds are present suggesting that the assembly is much stronger than for the other stickers.

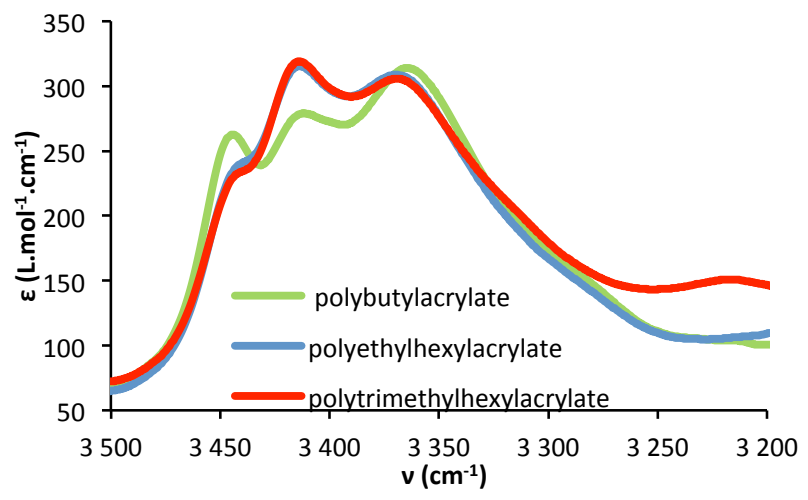

Fig. 9: Infrared spectra of various xylyl bisurea polyacrylates (Mn ca 8000 $\mathrm{g} / \mathrm{mol}$ ) in toluene at $4 \mathrm{mM}$.

The influence of the nature of the polymer on the assembly was studied by FTIR for a given sticker (xylyl bisurea) (Figure 9). In fact, the spectra are very similar for all the polyacrylates tested. In particular, the concentration of inter-urea hydrogen bonds $\left(3300 \mathrm{~cm}^{-1}\right)$ is the same. However the concentration of intramolecular hydrogen bonds between urea and ester functions $\left(3410 \mathrm{~cm}^{-1}\right)$ is slightly larger in the case of poly(3,5,5trimethylhexylacrylate) and poly(2-ethylhexylacrylate) compared to PnBA. This weak effect may be due to the slightly lower polarity induced by longer alkyl sidechains."

\section{Small Angle Neutron Scattering}

SANS measurements were used to derive information about the structure of the assemblies. The measurements were performed in deuterated toluene at low concentrations $\left(0.8 \mathrm{mM} / 6 \mathrm{~g} . \mathrm{L}^{-1}\right)$ to ensure that no interaction between scattering objects is present in the $\mathrm{q}$ range considered. Figure 10 shows the scattered intensities of the PnBAs bearing various urea stickers.

At high $\mathrm{q}$ values, $\mathrm{a}^{-2}$ dependence is found for all polymers. This is a characteristic for Gaussian chains. At low q values, three different behaviours are observed depending on the urea sticker. The MDI and tolyl bisurea PnBAs both show a low scattering intensity that reaches a plateau value. The data can be fitted with the form factor for a Gaussian chain (see $\left.\mathrm{ESI}^{\dagger}\right)$.

The weight average molar mass extracted from the fit is equal to the molar mass of the polymer, which means that no intermolecular assembly occurs in these conditions. This result unequivocally confirms our previous interpretation of the FTIR spectra: the $3410 \mathrm{~cm}^{-1}$ band is necessarily due to intramolecular hydrogen bonding (to ester groups) because it is the main band in these conditions (Figure 7). The xylyl bisurea PnBA has a very similar behaviour as the other bisurea PnBAs, except that the plateau is slightly higher, corresponding to a molar mass $50 \%$ larger than the individual polymer chains (see $\mathrm{ESI}^{\dagger}$ ). Moreover, at very low $\mathrm{q}$, the onset of a scattered intensity increase is visible and is probably associated with the presence of a minority second population in solution. Both features indicate that at this concentration, the xylyl bisurea PnBA has begun to assemble but that no large structures are formed.

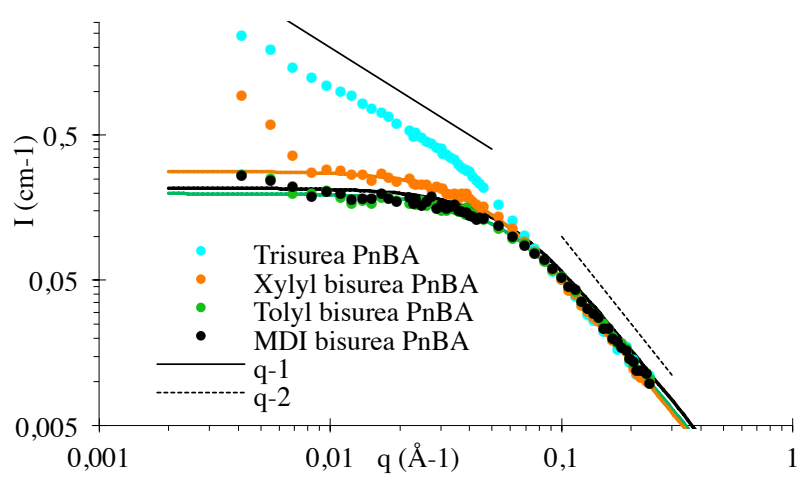

Fig. 10: SANS intensity (I) versus scattering vector (q) for solutions of PnBA ( $\mathrm{Mn} \mathrm{ca} 8000 \mathrm{~g} / \mathrm{mol}$ ) bearing various urea stickers in $\mathrm{d}_{8}$-toluene at $0.8 \mathrm{mM}$ (the straight lines represent the fit according to a Gaussian model).

Finally, in the case of the trisurea PnBA, the scattered intensity is characterized at low angles by a $\mathrm{q}^{-1}$ dependence covering more than one decade. This scattering feature is typical of long and rigid fibrillar scatterers. The fact that the $\mathrm{q}^{-1}$ dependence is maintained down to the lowest experimental $q$ values means that cylindrical objects with a rigid core longer than $200 \AA$, i.e. at least 40 stacked trisureas, are present. A more quantitative description of this curve by a suitable form factor will be the focus of a future study, but the significant fraction of intramolecular hydrogen bonding visible on Figure 7 indicates that the long and rigid objects dominating the SANS scattering curve are probably in equilibrium with a significant fraction of lower size aggregates; i.e. the assemblies are probably very polydispersed in length.

Overall, the SANS and FTIR results are in very good agreement. The trisurea PnBA is the most strongly associated of these polymers with self-assembly occurring at concentrations above 1 $\mathrm{mM}$. The bisureas PnBA are able to self assemble at concentrations of $10 \mathrm{mM}$ with the xylyl bisurea sticker being more efficient than the MDI and tolyl bisurea stickers.

\section{Conclusion}

We report the synthesis of well controlled polyacrylates bearing urea moieties in the middle of the chain. Through a functionalized initiator strategy, ATRP polymerization yields a wide range of polyacrylates of various molar masses (3 to $100 \mathrm{~kg} \cdot \mathrm{mol}^{-1}$ ), of various nature (ethylhexyl, trimethylhexyl and butyl acrylates) and of various strength of association, depending on the sticker (MDI bisurea $\sim$ tolyl bisurea $<$ xylyl bisurea $<<$ trisurea). The control of these polymerizations via ATRP resulted in polymers with a narrow polydispersity and a predictable molar 
mass. The properties of these polymers in solutions reveal a large influence of the urea sticker on the association. In particular, the polymers with a trisurea sticker in the middle of the chain seem of particular interest due to their ability to form long and rigid objects. We are currently investigating the bulk properties of these polymers.

\section{Acknowledgments}

Support from the French Agence Nationale de la Recherche is acknowledged (project ANR-10-BLAN-0801 Supradhesion). We thank François Boué (LLB, Saclay) for assistance with SANS experiments. Ludovic Dubreucq is thanked for MALDI-TOF analyses. Chirine Ben Osman and Vincent Lemaire are gratefully acknowledged for their help in this work.

\section{Notes and references}

${ }^{a}$ UPMC Univ Paris 06, UMR 7610, Chimie des Polymères, F-75005 Paris, France, and CNRS, UMR 7610, Chimie des Polymères, F-75005 Paris, France

$\dagger$ Electronic Supplementary Information (ESI) available: [Synthesis of initiators 6, 7 and $8-{ }^{1} \mathrm{H}$ NMR spectrum of PnBA CF151 - Kinetic monitoring of ATRP of 2-ethylhexylacrylate - SANS data treatment]. See DOI: $10.1039 / \mathrm{b} 000000 x$

\# Such a micropolarity effect has been reported for instance for disubstituted ureas ${ }^{54}$.

1. B. J. B. Folmer, R. P. Sijbesma, R. M. Versteegen, J. A. J. van der Rijt, and E. W. Meijer, Adv. Mater., 2000, 12, 874878 .

2. P. Cordier, F. Tournilhac, C. Soulié-Ziakovic, and L. Leibler, Nature, 2008, 451, 977-980.

3. Y. Chen, A. M. Kushner, G. A. Williams, and Z. Guan, Nature Chemistry, 2012, 4, 467-472.

4. W. H. Binder and R. Zirbs, in Hydrogen Bonded Polymers, ed. W. Binder, Springer Berlin Heidelberg, Berlin, Heidelberg, vol. 207, pp. 1-78.

5. F. Herbst, D. Döhler, P. Michael, and W. H. Binder, Macromol. Rapid Commun., 2013, 34, 203-220.

6. A. Bertrand, F. Lortie, and J. Bernard, Macromol. Rapid Commun., 2012, 33, 2062-2091.

7. J.-L. Wietor, D. J. M. van Beek, G. W. Peters, E. Mendes, and R. P. Sijbesma, Macromolecules, 2011, 44, 12111219.

8. K. Fuchise, R. Kakuchi, S.-T. Lin, R. Sakai, S.-I. Sato, T. Satoh, W.-C. Chen, and T. Kakuchi, J. Polym. Sci., Part A: Polym. Chem., 2009, 47, 6259-6268.

9. S. Abed, S. Boileau, and L. Bouteiller, Macromolecules, 2000, 33, 8479-8487.

10. H. S. Bazzi and H. F. Sleiman, Macromolecules, 2002, 35, 9617-9620.

11. X. Yang, F. Hua, K. Yamato, E. Ruckenstein, B. Gong, W. Kim, and C. Y. Ryu, Angew. Chem. Int. Ed., 2004, 43, 6471-6474.

12. K. P. Nair, V. Breedveld, and M. Weck, Soft Matter, 2011, 7, 553.

13. T. Ware, K. Hearon, A. Lonnecker, K. L. Wooley, D. J. Maitland, and W. Voit, Macromolecules, 2012, 45, 10621069.
14. J. Bernard, F. Lortie, and B. Fenet, Macromol. Rapid Commun., 2009, 30, 83-88.

15. M. H. Wrue, A. C. McUmber, and M. Anthamatten, Macromolecules, 2009, 42, 9255-9262.

16. B. D. Mather, M. B. Baker, F. L. Beyer, M. A. G. Berg, M. D. Green, and T. E. Long, Macromolecules, 2007, 40, 6834-6845.

17. E. M. Todd and S. C. Zimmerman, J. Am. Chem. Soc., 2007, 129, 14534-14535.

18. A. V. Ambade, S. K. Yang, and M. Weck, Angew. Chem. Int. Ed., 2009, 48, 2894-2898.

19. M. N. Higley, J. M. Pollino, E. Hollembeak, and M. Weck, Chem. Eur. J., 2005, 11, 2946-2953.

20. A. D. Celiz and O. A. Scherman, J. Polym. Sci., Part A: Polym. Chem., 2010, 48, 5833-5841.

21. A. Bertrand, S. Chen, G. Souharce, C. Ladavière, E. Fleury, and J. Bernard, Macromolecules, 2011, 44, 36943704.

22. A. Likhitsup, S. Yu, Y.-H. Ng, C. L. L. Chai, and E. K. W. Tam, Chem. Commun, 2009, 4070.

23. K. E. Feldman, M. J. Kade, T. F. A. de Greef, E. W. Meijer, E. J. Kramer, and C. J. Hawker, Macromolecules, 2008, 41, 4694-4700.

24. D. Greef, T. F. A, M. J. Kade, K. E. Feldman, E. J. Kramer, C. J. Hawker, and E. W. Meijer, J. Polym. Sci., Part A: Polym. Chem., 2011, 49, 4253-4260.

25. O. A. Scherman, G. B. W. L. Ligthart, R. P. Sijbesma, and E. W. Meijer, Angew. Chem. Int. Ed., 2006, 45, 20722076.

26. S.-H. Lee, M. Ouchi, and M. Sawamoto, Macromolecules, 2012, 45, 3702-3710.

27. R. F. M. Lange, M. Van Gurp, and E. W. Meijer, J. Polym. Sci., Part A: Polym. Chem., 1999, 37, 3657-3670.

28. O. Colombani, C. Barioz, L. Bouteiller, C. Chanéac, L. Fompérie, F. Lortie, and H. Montès, Macromolecules, 2005, 38, 1752-1759.

29. K. Yamauchi, J. R. Lizotte, and T. E. Long, Macromolecules, 2003, 36, 1083-1088.

30. E. Weiss, K. C. Daoulas, M. Müller, and R. Shenhar, Macromolecules, 2011, 44, 9773-9781.

31. F. Herbst and W. H. Binder, Polym. Chem., 2013, 4, 36023609.

32. R. Chapman, K. A. Jolliffe, and S. Perrier, Adv. Mater., 2013, 25, 1170-1172.

33. R. Chapman, K. A. Jolliffe, and S. Perrier, Polym. Chem., 2011, 2, 1956-1963.

34. S. Rosselli, A.-D. Ramminger, T. Wagner, B. Silier, S. Wiegand, W. Häußler, G. Lieser, V. Scheumann, and S. Höger, Angew. Chem. Int. Ed., 2001, 40, 3137-3141.

35. R. Chapman, M. Danial, M. L. Koh, K. A. Jolliffe, and S. Perrier, Chem. Soc. Rev, 2012, 41, 6023-6041.

36. S. Pensec, N. Nouvel, A. Guilleman, C. Creton, F. Boué, and L. Bouteiller, Macromolecules, 2010, 43, 2529-2534.

37. S. Catrouillet, C. Fonteneau, L. Bouteiller, N. Delorme, E. Nicol, T. Nicolai, S. Pensec, and O. Colombani, Macromolecules, 2013, accepted DOI : 10.1021/ma401167n

38. J. Courtois, I. Baroudi, N. Nouvel, E. Degrandi, S. Pensec, G. Ducouret, C. Chanéac, L. Bouteiller, and C. Creton, Adv. Funct. Mater., 2010, 20, 1803-1811.

39. E. Chernikova, A. Morozov, E. Leonova, E. Garina, V. Golubev, C. Bui, and B. Charleux, Macromolecules, 2004, 37, 6329-6339.

40. J. Huang, T. Pintauer, and K. Matyjaszewski, J. Polym. Sci., Part A: Polym. Chem., 2004, 42, 3285-3292. 
41. M. Reyes, X. Yu, and D. A. Shipp, Macromol. Chem. Phys., 2001, 202, 3268-3272.

42. S. G. Roos and A. H. E. Müller, Macromol. Rapid Commun., 2000, 21, 864-867.

43. Y. Reyes and J. M. Asua, Macromol. Rapid Commun., 2011, 32, 63-67.

44. N. M. Ahmad, B. Charleux, C. Farcet, C. J. Ferguson, S. G. Gaynor, B. S. Hawkett, F. Heatley, B. Klumperman, D. Konkolewicz, P. A. Lovell, K. Matyjaszewski, and R. Venkatesh, Macromol. Rapid Commun., 2009, 30, 2002 2021.

45. S. Piogé, L. Fontaine, J.-C. Soutif, E. Nicol, and S. Pascual, J. Polym. Sci., Part A: Polym. Chem., 2010, 48, 15261537.

46. M. Bednarek, T. Biedroń, and P. Kubisa, Macromol. Chem. Phys., 2000, 201, 58-66.

47. H. Nonaka, M. Ouchi, M. Kamigaito, and M. Sawamoto, Macromolecules, 2001, 34, 2083-2088.

48. Y. Kwak, A. J. D. Magenau, and K. Matyjaszewski, Macromolecules, 2011, 44, 811-819.

49. B. Isare, G. Pembouong, F. Boué, and L. Bouteiller, Langmuir, 2012, 28, 7535-7541.

50. R. L. Pelley and D. Wilmington, 1956.

51. V. Simic, L. Bouteiller, and M. Jalabert, J. Am. Chem. Soc., 2003, 125, 13148-13154.

52. F. Ouhib, M. Raynal, B. Jouvelet, B. Isare, and L. Bouteiller, Chem. Commun, 2011, 47, 10683

53. F. Lortie, S. Boileau, and L. Bouteiller, Chem. Eur. J., 2003, 9, 3008-3014. 